\title{
3. Demographic challenges of Europe in the new millennium: Swedish family policies as an answer to them?
}

Livia Sz. Oláh and Gerda Neyer

\section{INTRODUCTION}

Welfare states have changed greatly in the past few decades, manifested in retrenchment, deregulations and reduced state engagement in traditional social protection, unlike the Golden Age of Welfare in the mid 1940s to mid 1970s (Palier 2010; Wincott 2013). Back then, based on the dominant family structure of the mid twentieth century, social policies targeted the male breadwinner with an industrial job. Indeed, the rationale of the post-war welfare state was to protect men as providers, and thus their families, against the risk of welfare losses when not being able to work for pay due to illness, unemployment or old age. Women could uphold a decent living standard in the face of these old social risks via stable marriage (and upon widowhood) as they were expected to 'de-commodify'; that is, to give up work when entering marriage or having the first child (Bonoli 2007; Orloff 1993). The implicit gender contracts of the 'housewife era' relegated women to unpaid work in the family, and made their welfare, social and economic status dependent on that of their husbands (Pateman 1988).

From the 1970s onwards, however, post-industrial transformations have increasingly come to characterise advanced societies. Deindustrialisation and tertiarisation of employment resulted in changing labour markets attracting large masses of women into the labour force. These developments coincided with increasing destandardisation of employment, career interruptions and deregularisation of full-time and standard work contracts, creating new social and economic risks for families (Bonoli 2007; Charles 2005). The Nordic and the English-speaking countries were among the first to enter the post-industrial stage of economic development. Continental and Southern European societies followed this path with a delay of two to three decades. In the 1990s and early 2000s, Central-Eastern Europe, including the Baltic countries, were to handle 
challenges around the transformation of their socialist economies into a capitalist market-based system (Gros and Steinherr 2004), and this transition is still ongoing in many of the region's countries.

The socioeconomic transformations brought along by post-industrialisation altered not only the labour market, but also the gender division of labour in families and, related to this, family patterns and structures. Women's labour force participation, while reducing their dependence on the male breadwinner, contributed to growing family instability, and accentuated the quest for solutions to combine paid work and domestic responsibilities. Lone parenthood and diminished opportunities to reconcile an economically sustainable employment with family life emerged as new social risks, particularly for women and children, who were inadequately covered by 'old' male-breadwinner-oriented welfare states (Taylor-Gooby 2004). This gave rise to calls for a new welfare state and new family policies with new gender contracts, new family forms and equal opportunities for children (Esping-Andersen et al. 2002).

In this chapter we address the new social risks related to family changes and the resulting changing demographics of Europe, relying on data from established databases such as Eurostat. We pay special attention to the interplay with changing gender roles. Thereafter we present the family policy measures enacted in Sweden, the poster country of the social investment strategy aimed at tackling new social risks of new family biographies, with emphasis on developments from the 1990s onwards. In the concluding thoughts we briefly summarise the main lessons for the policy challenges ahead.

\section{DEMOGRAPHIC CHALLENGES}

The welfare provision in the post-war welfare state was structured around the single male-earner model, assuming stable family and employment life courses. However, since the 1970s new patterns of family and gender behaviour have emerged. Given that they qualitatively differ so much from earlier post-war developments, the demographic literature has recognised them as jointly constituting the Second Demographic Transition (Lesthaeghe 2010). In this section, we highlight the main features of family changes in Europe, which together impose what we call 'demographic challenges' on post-industrial welfare states, and we compare them to the developments in Sweden.

\section{Low Fertility and Population Ageing}

A feature of the new demographic trends that received the most attention by policy-makers is persistent low fertility (Macura et al. 2005). Throughout human history, this is the first time that fertility levels have been below the so-called replacement level of 2.1 children per woman on average in a large 
number of (advanced) societies for decades, with severe consequences for the age structure of the population in the long run. The pace and the range of fertility decline have, however, varied substantially across countries in Europe. Despite national variations, some distinct country clusters have emerged since the 1970s (Figure 3.1). Demographers and welfare state researchers tend to relate this development to European welfare and family policy regimes and the social conditions they create for childbearing (see Esping-Andersen 1999; Thévenon 2011):

- Nordic countries (Denmark, Finland, Iceland, Norway and Sweden): the Social Democratic welfare regime with mainly universal social provisions, promoting the dual-earner family model and gender equality,

- Anglo-Saxon countries (the United Kingdom and Ireland): the Liberal welfare regime with usually means-tested support and the dominance of market-based solutions in welfare provision,

- Western Europe (Belgium, France, Luxembourg and the Netherlands): the Conservative welfare regime that supports men's primacy at the labour market but also provides possibilities via policy measures for women to combine paid work and family responsibilities,

- German-speaking countries (Austria, Germany and, given the welfare logic followed, Switzerland, its several official languages notwithstanding): also the Conservative welfare regime but less supportive of women's employment than the West European group,

- Southern Europe (Greece, Italy, Portugal and Spain): the Familistic welfare regime with extremely limited family support and pronounced gender-role differentiation (Lewis 2006), and

- Central-Eastern Europe (Bulgaria, Czech Republic, Estonia, Hungary, Latvia, Lithuania, Poland, Romania, Slovakia and Slovenia): the Transition Post-Socialist cluster with large variations in the range of state support to families and in facilitating the combination of paid work and family for women.

Fertility declined to less than two children per woman first in the German-speaking, the Western European and the Nordic countries in the early 1970s (Figure 3.1), but even earlier in some societies within these groups, most specifically in Sweden. Southern Europe entered the low-fertility path in the early 1980s, joined by the Anglo-Saxon countries and Central-Eastern Europe at the end of that decade. In German-speaking countries and the latter clusters, with the exception of Anglo-Saxon countries, fertility levels have lingered even below the so-called critical level of low fertility (1.5 children per woman on average), known to accelerate population ageing (McDonald 2006), from the early-mid 1990s onward. Fertility increased in the Nordic 
4.0

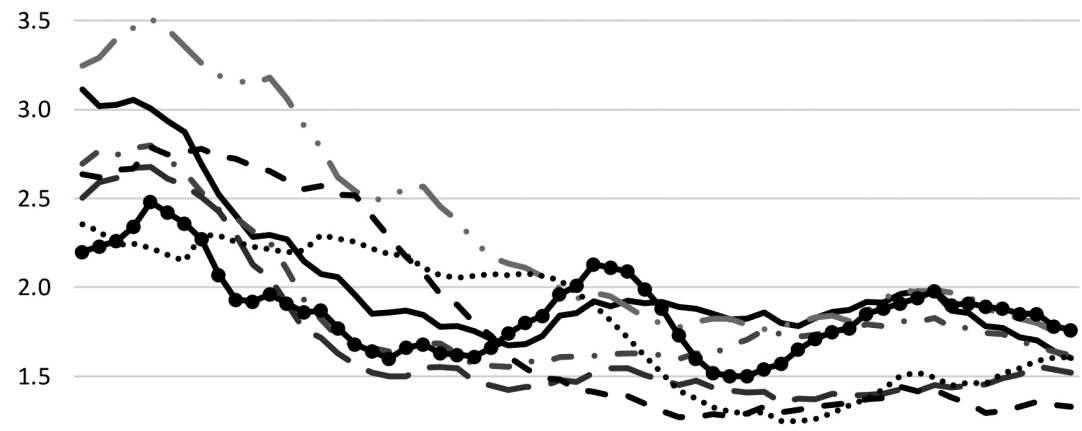

1.0

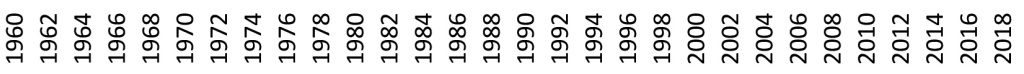

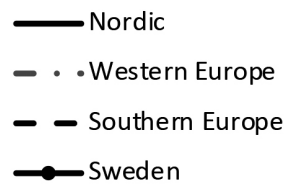

- Anglo-Saxon

- - German-speaking

...... Central-Eastern Europe

Notes: Unweighted data; means for each group. Countries are grouped as follows: Nordic - Denmark, Finland, Iceland and Norway; Anglo-Saxon - the United Kingdom and Ireland; Western Europe - Belgium, France, Luxembourg and the Netherlands; German-speaking Austria, Germany (for the years 1960-1989, West Germany only) and Switzerland; Southern Europe - Greece, Italy, Portugal and Spain; Central-Eastern Europe - Bulgaria, Czech Republic, Estonia, Hungary, Latvia, Lithuania, Poland, Romania, Slovakia and Slovenia. Sweden is depicted separately.

Source: INED (2013) for the years 1960-2008; Eurostat (2020) for the years 2009-2018; own calculations.

Figure 3.1 Period total fertility rates (average number of children per woman) in Sweden and different country clusters in Europe, 1960-2018

countries from the late 1980s, and in Anglo-Saxon countries and Western Europe from the early 1990s, until the Great Recession brought along a new decline in the 2010s. Sweden displayed a rather unique pattern, reaching the replacement level in 1990, followed by a dramatic fertility decline at the end of the decade due to an economic crisis. In the 2000s, Sweden experienced a fertility recovery close to the replacement level, and a slow decline in recent years. At the end of the 2010s, with policy strategies in Europe more strongly geared towards austerity (Lennartz and Ronald 2017), fertility seems to con- 
verge across country groups at a low level but, with the exception of Southern Europe, above the critical margin.

Another trend that accompanies the fertility decline is the increasing mean age of entering parenthood. During the male-breadwinner era, women in Europe had their first child in their early or mid twenties on average. Since then, childbearing has been increasingly postponed, related to the rise of female employment levels and women's educational aspirations (Blossfeld 1995). In the early twenty-first century, women enter motherhood first in their late twenties or even early thirties, although somewhat earlier in Central-Eastern Europe and the Baltics. As the ability for reproduction declines from the late thirties, the ageing of fertility is likely to contribute to the 'fertility gap', an acknowledged policy concern referring to the difference between the intended number of children, which remains above the replacement level across Europe, and the much lower realised fertility levels (Beaujouan and Berghammer 2019).

The main policy concern with low fertility from a welfare system point of view relates to the diminishing stock of future taxpayers, as the labour force shrinks due to fewer young people entering it than old ones leaving for retirement. Long-term below-replacement fertility levels also contribute to the ageing of the population, as the proportion and numbers of elderly increase beyond the level that is considered fiscally sustainable, jeopardising the future of the welfare state (McDonald 2006). Indeed, a large share of elderly in the population undermines the intergenerational contract, central for the redistribution of incomes coordinated by the welfare state (Taylor-Gooby 2004). There should be enough young people to fill in the position of currently middle-aged in the future so when turning old they can expect levels of support similar to those they provide now (Komp and Van Tilburg 2010). Low fertility and population ageing thus challenge the intergenerational contract, and increase the burden to provide care for the elderly.

\section{Family Instability and Implications for Household Structures}

Another important challenge of the marriage-based provisions of welfare in post-war welfare states is the substantial weakening of the supremacy of marriage in the European family landscape from the late 1960s onwards (Sobotka and Toulemon 2008). This pattern again emerged first in Sweden and the Nordic countries, linked to an increasing prevalence of non-marital cohabitation, followed by Western Europe, the Anglo-Saxon and the German-speaking countries in the mid 1970s. High marriage rates prevailed in Central-Eastern Europe and the Baltics, but decreased rapidly after the fall of state socialism. In parallel, non-marital cohabitation increased with pronounced country variations (rare in Poland, but common in Estonia). In Southern Europe, marriage rates only started to decline rapidly in the early twenty-first century. 
All over Europe, declining marriage propensities were paralleled by an increasing mean age of entering marriage, exceeding the mean age of first motherhood in many countries. Sweden has led the other European countries in this development since the early 1970s. The postponement has been interpreted as the materialisation of people refraining from long-term commitments, seen as a main feature of the Second Demographic Transition (Lesthaeghe 2010). Related to the rising prevalence of non-marital cohabitation, researchers also noted an upsurge of extramarital childbearing throughout Europe, starting in Sweden and other Nordic countries in the late 1960s, followed by other country clusters in the 1980s and Southern Europe in the early 2000s. In recent years, about one-third of births occurred out-of-wedlock in Southern Europe and the German-speaking countries, around 40 per cent in Anglo-Saxon countries and Central-Eastern Europe, and more than half of all births in Sweden and other Nordic countries and Western Europe (Eurostat 2020).

The changing partnership and childbearing patterns also have implications for family stability. Consensual unions are more fragile than marriages, given the partners' lesser commitment to each other and low, if any, legal barriers to break-up (Perelli-Harris and Sánchez Gassen 2012). Even among families with children, the risk for family dissolution is much higher in cohabiting relationships than in marriages (Booth and Crouter 2002). Nevertheless, divorce rates increased in all country clusters, with Sweden among the forerunners, beginning in the 1970s, but not before the late 1990s in Southern Europe. Also, family reconstitution, that is, re-partnering with children and possibly having children with a new partner, has become rather common in Europe. Many children live with a step-parent and often with a half-sibling within a few years after their parents' break-up. Such families are even more fragile than first partnerships, thus further strengthening the trend of family instability. In addition, a non-negligible proportion of children live with a lone parent. Break-ups becoming more common in the less educated segment of societies in recent decades (Matysiak et al. 2014) adds to the new social risks posing new challenges to welfare states.

\section{Increasing Population Heterogeneity Due to Immigration}

New social risks are not confined to family fluidity, but also include changes in the ethnic composition of populations in Europe. Between 1996 and 2010, the proportion foreign-born in Western Europe grew from around 8 to 14 per cent of the population, exceeding such a share in the USA (D'Amuri and Peri 2014). This proportion has increased even further since then. The majority of the new immigrants are of non-European origin, coming as labour migrants, their family members or as refugees. Their labour force participation rates vary across Europe. The Nordic countries, and Sweden especially, while listed at 
the top in terms of social rights covering immigrants and natives equally, have surprisingly large differences in native-immigrant labour force participation rates, and tend to be among the countries with the greatest negative employment disparities in the OECD (Brochmann and Hagelund 2011). Researchers argue that the reason for the large disparities are the high female employment rates and high public service provision in the Nordic countries reducing labour opportunities for the often low-skilled migrant labour (ibid.).

Given low fertility and population ageing in Europe, immigration has often been discussed from the viewpoint of 'replacement migration'; that is, that immigrants' labour force participation and fertility should compensate for below-replacement fertility levels and sustain the work force and the welfare state (for a review of this debate, see Wilson et al. 2013). Due to a shift of attitudes towards immigration, their often higher fertility compared to the natives has, however, become increasingly considered a sign of a lack of integration. The diversification of immigration has turned the attention towards whether globalisation and substantial migrant inflows lead to welfare state expansion or retrenchment. A recent analysis over the 1990s to 2010 shows that social welfare spending in relation to gross domestic product increased with little change in welfare generosity levels, in line with the growing needs for social protection (Fenwick 2019). Another aspect is changing public attitudes towards welfare redistribution. Support for the welfare state was argued to have become 'immigrationised'; that is, directly related to people's attitudes about immigration (Burgoon and Rooduijn 2020). Analyses revealed that the share of foreign-born people, the level of welfare spending and migrants' welfare dependency relative to the natives govern anti-immigration sentiments and develop into anti-solidarity effects undermining support for redistribution in general, posing another challenge for the welfare state (Burgoon and Rooduijn 2020; Finseraas 2008).

\section{CHANGING GENDER ROLES}

The changes in family patterns, often described as the individualisation of families, have been paralleled by evolving gender roles, known as the gender revolution (Goldscheider et al. 2015). Most of the changes relate to women's roles expanding to include economic provision to the family on (nearly) equal footing with men. In this respect, Central-Eastern Europe was a vanguard with high levels of female and maternal full-time employment in the socialist period, embodying the regime's perception of gender equality. When the institutional structure that supported the combination of paid work and family broke down in the transition period of the 1990s, women's economic activity declined substantially, and the process towards recovery has been slow ever since. For the rest of Europe, Sweden and other Nordic countries acted as 
a forerunner not only of new family trends but also regarding the increase of women's and mothers' labour force participation from the 1970s onwards, displaying the highest female employment rates even today (Oláh et al. 2018). Other country clusters joined the trend during the 1980s, Southern Europe lagging behind up until the 2010s. In recent years, the gender employment gap has greatly diminished across Europe, although with further pace for catching up for both Southern Europe and Central-Eastern Europe (Figure 3.2).

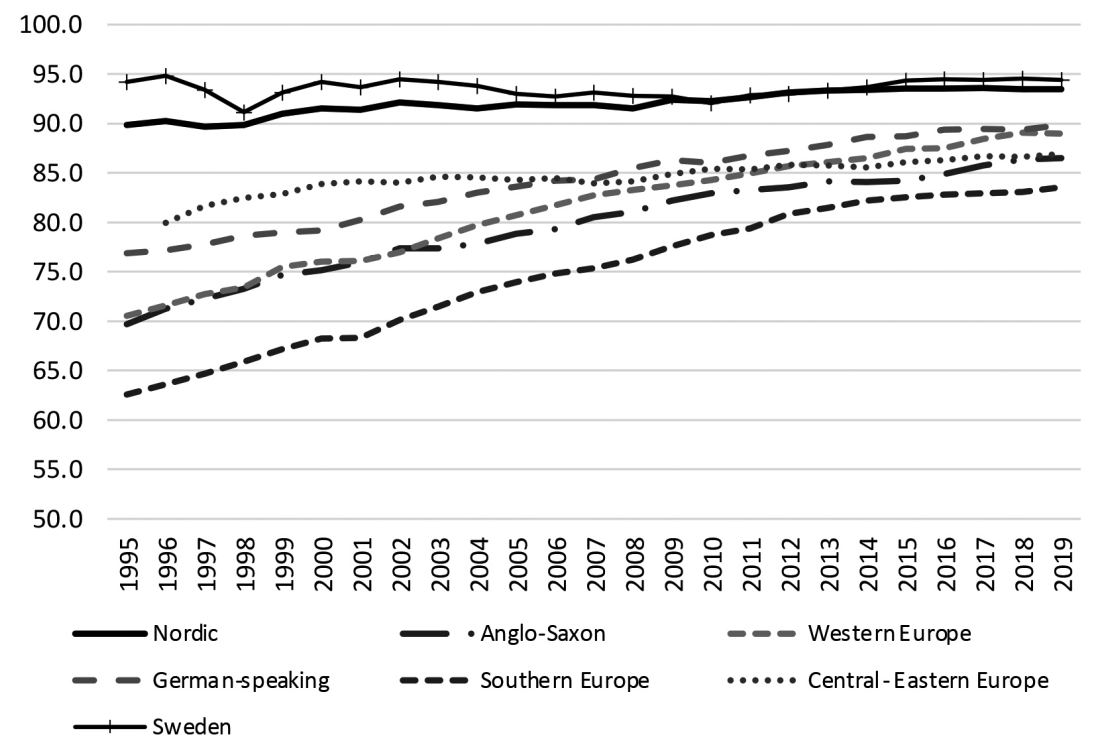

Notes: Unweighted data; means for each group. Countries are grouped as in Figure 3.1. Sweden is depicted separately.

Source: Eurostat (2020), own calculations.

Figure 3.2 Gender differences in labour market activity (women's activity rate in proportion of men's rate) at ages 20-64 in Sweden and different country clusters in Europe, 1995-2019

Economic theorists have seen women's increasing economic independence as the main driver of family changes, with respect to both the postponement of family formation and childbearing, and the erosion of family stability (Becker 1991). However, unlike among men, female labour force activities involve much part-time work in most country clusters, except for Southern Europe and Central-Eastern Europe, where labour market structures are quite rigid. Hence, despite the reduced gender gap in paid work, it is the one-and-a-half-earner model rather than the dual-earner family that has been firmly established 
across Europe (Daly 2011). To some extent, this is surprising, because women have gained educational advantage over men. From the 1990s onwards women's share among the highly educated exceeds that of men, with important implications for couple relationships. Homogamy - that is, equal educational attainment among partners - has become the dominant pattern, followed by hypogamy; that is, the woman's educational attainment exceeds that of her partner (Van Bavel et al. 2018). These educational pairings have basically replaced the old pattern with men's superior economic position in families all over Europe in recent decades.

However, women's gain in earning and bargaining power within the couple has not yet translated into gender-equal family and work-life arrangements. Time-use studies revealed that the carrying-out of unpaid care and housework in most families remains gendered. There have been some (smaller) changes in men's gender role, particularly in relation to their children, recognised in the literature in the concept of 'the new father' (Ranson 2001). The second phase of the gender revolution, namely men's engagement in care and housework on equal terms with women, has only just begun. Demographic theories regard the resulting dual burden on women as a reason for low fertility and the increasing instability of couple relationships (Goldscheider et al. 2015). For example, women's exclusive responsibility for the home sphere in Central-Eastern Europe and Southern Europe is considered to contribute to the very low fertility levels in these regions, while the higher fertility levels in Sweden and the Nordic countries are attributed to men's widespread engagement in childrearing.

Reconciling paid work and family life unequally has emerged as a new social risk for families and gender relationships. Increasingly, both women's and men's income are needed to provide for a family, but time and personal energy are limited resources. Men's engagement in care and household chores as well as state or market provisions to de-familialise (parts of) care and housework have become necessary components to achieve work-family balance and well-being (Bonoli 2007). In this respect, the Nordic countries, and Sweden in particular, are often seen as models to be followed by European welfare states. These countries have adjusted their welfare state policies to address the new social risks and are thus regarded as better equipped to meet the social, family and welfare state challenges that jeopardise the intergenerational contract and the welfare system's sustainability in the long run.

\section{SWEDISH FAMILY POLICIES: CONTENT, ORIENTATION AND OUTCOMES}

Changing structures of labour markets and social risks have elicited new welfare strategies. In many countries, the emphasis of social protection has 
shifted from simple social provision to social-investment-oriented policies, the latter most fully implemented in the Nordic countries from the 1990s onwards. The origin of the paradigm lies in the 1930s, in particular in Alva and Gunnar Myrdal's social and family policy suggestions to tackle that time's low-fertility crisis in Sweden. The Myrdals conceived social policies as an investment in individuals and the future of society by supporting women's employment and various family configurations alongside the male-breadwinner model. The emergence of new social risks has contributed to the recent revival of the approach (Morel et al. 2012).

The core features of a social investment welfare state are active labour market policies, human capital investment starting with early childhood education, publicly funded childcare and old-age services, family policies that promote employment irrespective of care obligations and gender equality in all aspects of public and private life (ibid.). This proactive approach combined with universal welfare provision is likely to impede the development of severe social problems. Therefore, we address key policy measures in Sweden, the pioneer of the social investment paradigm and of employment-oriented family policies. We focus on family policies since they are considered an essential response to the demographic challenges discussed above, namely low fertility, changing household structures and gender relationships, as they provide a means of social integration and equality.

\section{Parental Leave Scheme: Flexible, Employment-Oriented and Care-Facilitating}

In 1974, Sweden was the first country in the world to implement a gender-neutral parental leave program with an income-related benefit and job protection. The benefit level was originally 90 per cent of a parent's previous gross income. Like all social benefits, it was lowered during the economic crisis of the 1990s, first to 75 per cent of previous income in the mid 1990s, then raised to 80 per cent at the end of the decade. Currently (2020), it is 77.6 per cent up to a certain ceiling. However, collective agreements ensure extra payments to most employees to cover the loss of income, even beyond the ceiling. State employees, for example, receive 90 per cent of their total income as leave benefit, the ceiling notwithstanding (Duvander et al. 2017). Since its introduction, eligibility to income-related parental leave benefit has been based on a parent having worked for at least 240 days before the delivery or before using the leave. Parents who do not fulfil this requirement receive a low flat-rate benefit (currently 250 Swedish crowns, or about 25 euros, per day).

The main aim of introducing a gender-neutral, income-related parental leave scheme was originally to encourage women's labour force participation and to enable women to both be employed and have children. By facilitating parents' 
mutual engagement in the care for their children, the scheme sought to also promote gender equality (Oláh and Bernhardt 2008). Although the parental leave scheme was directed at both parents, mainly mothers used it, as no specific regulation enforced leave-sharing. To incentivise fathers' involvement, in 1995 one month's leave was reserved for each parent on a 'use it or lose it' basis, known as the 'father's quota'. At the same time, the leave was individualised, requiring (electronically) signed consent by a parent for the other parent to be able to use more than half of the total leave. This applied also to parents not living together but both having custody for a child, which included the vast majority of separated parents (Ferrarini and Duvander 2010). Except for one month in the first year after the birth, the so-called double days, parents cannot use the leave at the same time. The number of reserved months was increased to two in 2002 and to three in 2016, making the individualisation of parental leave more and more explicit.

Currently each parent can use 240 days with benefit per child (480 days in total), 90 days of which are non-transferable to the other parent. For 180 of these 240 days, a parent receives an income-related parental leave benefit, and for 90 days a flat-rate benefit of 180 Swedish crowns (about 18 euros) per day. In all, 384 days must be used in the first four years after the birth. The rest (96 days) can be used any time before the child turns 12 . Leave of absence from work is allowed even if no leave benefit is used during the child's first 18 months (the use of such leave does not affect the number of leave days with benefit). Moreover, the Swedish parental leave scheme has a unique flexibility, allowing parents to take half-days, quarter-days or one-eighth of a day instead of full days. This flexibility, together with the options of paid and unpaid leave days, makes it possible for parents to combine employment and taking care of one's child at home as best fits, and it allows for the parental leave to be stretched out to facilitate everyday life puzzles beyond the immediate toddler years (Duvander and Viklund 2020). Parental leave is a parental right; employers cannot deny parents from taking time off for parental leave.

Beside parental leave, parents are also entitled to temporary parental leave to care for their sick children up to 120 working days per year and per child until the child is 12 years old, with the same flexibility and income-related benefit as for parental leave (although with a lower ceiling). Temporary parental leave may be granted for older children and/or for more than the 120 days in case of severe illness or extensive care needs. Part of the temporary parental leave may also be taken if the usual carer of the child is sick. The Swedish parental leave program is thus a true activation and social-investment-oriented measure of a post-industrial welfare state, as it offers a wide range of possibilities to take leave, while not distinguishing between mothers and fathers nor by partnership type. It is based on individual eligibility, and the rules of provision do not depend on the other parent's circumstances. The leave schemes are intended 
to facilitate employment for each parent while having a child and to promote gender-equal parenting, in line with the earner-carer orientation of Swedish family policy.

\section{Public Childcare: From Promoting Parents' Employment to Equal Opportunities of Children}

The public childcare system is the second main component of Swedish family policy, facilitating partial defamilialisation of care. Its foundations were laid in the late 1960s to promote mothers' employment retention. In 1975 municipalities became obliged to provide at least half-day care for all 6-year-old children free of charge. For younger children, day care was related to a fee to be paid. However, access was ensured only if the parents were employed or studying. Increasingly, the aim and focus of public childcare broadened from facilitating parental employment to providing equal early childhood education to all children. Based on the 1995 Act on childcare, children are guaranteed to have a place in public childcare within three to four months upon parents' requests. Regardless of the parents' activity, public childcare is provided on a full-day basis for all children aged 1 to 6 . Since the early 2000s, even children whose parents are unemployed, on leave or in other ways outside the labour market have full rights to public childcare, but at reduced hours (Ferrarini and Duvander 2010), currently 15 hours per week.

Formal childcare is offered not only by municipalities, but since the $1990 \mathrm{~s}$ also by private providers and cooperatives. All providers have to align with the rules of parental fees, are financed to the same extent by subsidies from the municipality and have to meet the same regulations and curriculum standards. In order to eliminate regional differences in costs, a system of maximum fees, the so-called maxtaxa that parents can be charged for, was introduced in 2002. The fee is proportional to the parents' income up to a certain ceiling and dependent on the number of children they have in day care. The amount paid may be maximally 3 per cent of the household's income for the first child, 2 per cent for the second, and 1 per cent for the third. There is no fee for any further children. Since 2004, children over 4 have a right to public childcare of 15 hours a week free of charge (ibid.). Public childcare is highly subsidised so that parental fees cover only about 10 per cent of the total costs, demonstrating the social-investment nature of the service.

From the start, public childcare was designed to ease challenges around the combination of child-raising and paid work, removing obstacles to employment for parents with preschool-aged children, especially mothers, hence promoting gender equality. The provision of childcare services enables both parents to support their family economically; it thus reduces the risk of poverty and contributes to the welfare of children. In addition to increasing mothers' 
employment, childcare was recognised early on to have a crucial role in the pursuit of social equality by mitigating differences in children's life chances, especially for those of disadvantaged backgrounds. Providing affordable, full-day, high-quality early childhood education based on a pedagogically informed curriculum and with educated staff ensures meeting this aspiration.

\section{Child Home-Care Allowance and Gender-Equality Bonus: Failed Policy Attempts}

Along with the successful policy measures discussed above, some relatively recent reforms turned out to be a failure. The strong gender-equality-based earner-carer orientation of Swedish family policy notwithstanding, coalition governments - not including the Social Democrats - attempted twice to introduce a child home-care allowance that opposed the basic endeavour of involving both parents in earning as well as caring activities. In favour of a traditional family-work arrangement but in modern packaging, the policy rhetoric around the first introduction in 1994 referred to it as aiming to increase freedom of choice with respect to the care for children, although it basically sought to strengthen re-familialisation of care. The timing was not a coincidence, as it accompanied the reform of the first reserved month to each parent in the gender-neutral parental leave scheme, in force from 1995. The latter reform sought to increase gender equality in care, incentivising fathers, while the home-care allowance could counteract such efforts, providing an untaxed flat-rate benefit for home care of children aged 1 to 3 and not using public childcare (Ferrarini and Duvander 2010). The low payment level made the measure unappealing to fathers, turning the home-care allowance into a tool also for re-gendering care. It was abolished after a few months upon a change of government.

The child home-care allowance was reintroduced in 2008, again with the alleged aim to increase freedom of choice for care. The amount was 340 euros per month, to be paid by municipalities to parents who had used at least 250 days of paid parental leave and wanted to care for their child at home thereafter. There was no previous work requirement, and parents could be employed, but not receive any other benefit, such as unemployment benefit or social assistance. The child home-care allowance never gained popularity in Sweden. Only about one-third of the municipalities introduced the option, and 4 per cent of all parents, mainly mothers with weak labour force attachment, including the foreign-born, used it (Duvander and Ellingsæter 2016). The measure was abolished in 2016.

To counter the potentially undermining effect on gender equality of the child home-care allowance, a gender-equality bonus was introduced simultaneously in 2008. It was a tax reduction paid for every day a father used 
parental leave beyond the days that were reserved for him. Parents who fully shared the leave could receive about 1,500 euros extra (Duvander and Ferrarini 2013). However, the regulations were too complex and confusing. Even after some simplification in 2012 of the administrative procedure linked to it, the gender-equality bonus remained rather ineffective and was abolished in 2017. Being a tax reduction, the measure implied a delay for the parents to benefit from it, and its failure also shows the importance of a reform being easily understandable for the target population. The fate of the child home-care allowance indicates instead that the social-investment orientation of family policies in Sweden has become a social norm that may prevent a return to more gender-segregating family policies.

\section{Societal Outcomes}

Swedish family policies do not contradict the social-investment orientation of other social policies, strengthening the logic of the entire welfare system. Active labour market policies focus on maintaining and advancing human capital during unemployment, while high income-related benefit levels prevent a decline into poverty. The educational system allows individuals to upgrade, advance or change their education throughout their life course. Swedish family policies, aligned with active labour market and consistent gender-equality policies promoting full employment and the dual-earner model, are an acknowledged success in providing protection in face of new social risks (Bonoli 2007). The outcomes are internationally high levels of female labour force activity, including of mothers with young children; relatively high fertility and a balanced population age structure; high prevalence of new fatherhood, with men's active engagement in their children's care; and relatively low child poverty despite high levels of family instability (OECD 2020). Various features of family policy measures have contributed to these advantageous outcomes.

The gender-neutral parental leave scheme combined with income-related benefit of a high replacement level not discriminating between mothers and fathers, but incentivising them to engage both in earning and caring, was a key labour-activation measure for women, and it pushed men to become active fathers. The latter effect was increased mainly by the father's quota, as losing leave days if not taken by the father motivated mothers to involve the fathers in the care of children. Even vis-à-vis employers, this feature strengthened fathers' role as active parents, although the uptake is polarised by social group and income. The highest strata is the most likely to use father's leave, as the concept of gender-equal parenting is more fully embraced by those mothers and fathers (Duvander and Viklund 2020). 
Fathers' parental leave uptake is also positively associated with second-birth propensities, keeping fertility at a reasonable level (Oláh and Bernhardt 2008). Moreover, the father's quota is shown to be quite effective in involving immigrant fathers in their children's care, strengthening societal integration (Mussino et al. 2018). Both immigrant mothers and immigrant fathers use less parental leave than Swedish mothers and fathers, related to their lower labour market integration. Their use of parental leave increases with the duration of their stay in Sweden. However, the most gender-equally used measure is the temporary parental benefit to care for sick children, with fathers taking 43 per cent of such leave days.

Parents', especially mothers', labour force participation has also been facilitated by high-quality public childcare, increasing options to ease social risks around the reconciliation of paid work and family life. Thus, poverty risks do not escalate despite high family instability and the variety of family structures children are brought up in (OECD 2020). Research has even shown that children in shared physical custody living alternately with either parent after their union dissolution, which is a rather common arrangement among separated parents in Sweden, experience lower levels of stress than children who live only or mostly with one parent, irrespective of parental income (Turunen 2017). Childcare provision also supports social equality by reducing the gap in children's life chances, no matter of any (dis)advantaged backgrounds. This is related to public childcare use being nearly universal in Sweden. In the 2010s, about half of the 1-year-olds were cared for by their parents using parental leave, while the rest attended public childcare, along with 90 per cent of the 2-year-olds and 94 per cent of children aged 3 to 5 (Skolverket 2020). The high rates of utilisation also demonstrate the high social acceptance of childcare services as part of the social investment paradigm and universal welfare provision Sweden is known for.

\section{CONCLUDING THOUGHTS}

Changing labour markets and a previously unprecedented diversity of family constellations annihilating the gender contract of the male-breadwinner era brought along new social risks to accompany old risks for post-industrial welfare systems to handle. The individualisation of families proved the earlier, marriage-based provision of welfare inadequate, putting reconciliation of paid work and family responsibilities in the forefront to reduce social and economic risks for adults and children alike. Moreover, changing demographics due to very low fertility and ageing populations as well as increasing population heterogeneity challenge the viability of the intergenerational contract and the legitimacy of redistribution, which are at the heart of the welfare state. Therefore, the Swedish example is especially valuable, since Sweden managed to keep 
fertility from plummeting and remaining at very low levels, preserving a rather stable population age structure and keeping new social risks at bay despite high levels of family instability in society. The social investment strategy followed from the 1990s onwards combined with employment-oriented family policy offers some valuable lessons for welfare systems in the post-industrial era.

An essential aspect is that Swedish family policies are not geared to support a specific family form, such as marriage, but are rather directed at the individual, independent of family structure. The main aim is to reduce socioeconomic differences and gender differences in employment and the family, and ultimately to ensure social and gender equality for all. Hence, Swedish family policies are designed to support the employment of all adults and to enable women and men to reconcile paid work and care for their children, even in the case of separated parents. When gender-neutral policies prove largely ineffective to break old gender patterns of care, policy-makers do not shy away from gendered incentives to promote gender equality, such as the father's quota in the parental leave scheme, which can also function as a tool for migrants' social integration. Last but not least, service provision is better aligned with the principle of universalism in the (re)distribution of welfare than cash transfers; hence, offering all children high-quality early childhood education via the public childcare system is an investment benefiting the entire society in the long run.

\section{ACKNOWLEDGEMENTS}

We gratefully acknowledge financial support to Livia Sz. Oláh from Stockholm University via the research program Ageing Well - Individuals, Families and Households under Changing Demographic Regimes in Sweden (grant number 2016-07115) by the Swedish Research Council for Health, Working life and Welfare (FORTE), and to Gerda Neyer via the Project on Fertility Intentions, Fertility Considerations and Fertility Decline in Sweden (Dnr 2020-01976) by the Swedish Research Council.

\section{REFERENCES}

Beaujouan, Eva, and Caroline Berghammer (2019), 'The gap between lifetime fertility intentions and completed fertility in Europe and the United States: A cohort approach', Population Research and Policy Review, 38 (4), 507-535.

Becker, Gary S. (1991), A Treatise on the Family (enlarged ed.). Cambridge, MA: Harvard University Press.

Blossfeld, Hans-Peter (ed.) (1995), The New Role of Women: Family Formation in Modern Societies. Boulder, CO: Westview Press. 
Bonoli, Giuliano (2007), 'Time matters: Postindustrialization, new social risks, and welfare state adaptation in advanced industrial democracies', Comparative Political Studies, 40 (5), 495-520.

Booth, Alan, and Ann C. Crouter (eds) (2002), Just Living Together: Implications of Cohabitation on Families, Children and Social Policy. London: Routledge.

Brochmann, Grete, and Anniken Hagelund (2011), 'Migrants in the Scandinavian welfare state: The emergence of a social policy problem', Nordic Journal of Migration Research, 1 (1), 13-24.

Burgoon, Brian, and Matthijs Rooduijn (2020), “'Immigrationization” of welfare politics? Anti-immigration and welfare attitudes in context', West European Politics. https://doi.org/10.1080/01402382.2019.1702297 (accessed August 1, 2020).

Charles, Maria (2005), 'National skill regimes, postindustrialism, and sex segregation', Social Politics: International Studies in Gender, State \& Society, 12 (2), 289-316.

D'Amuri, Francesco, and Giovanni Peri (2014), 'Immigration, jobs, and employment protection: Evidence from Europe before and during the Great Recession', Journal of the European Economic Association, 12 (2), 432-464.

Daly, Mary (2011), 'What adult worker model? A critical look at recent social policy reform in Europe from a gender and family perspective', Social Politics: International Studies in Gender, State \& Society, 18 (1), 1-23.

Duvander, Ann-Zofie, and Anne Lise Ellingsæter (2016), 'Cash for childcare schemes in the Nordic welfare states: Diverse paths, diverse outcomes', European Societies, 18 (1), 70-90.

Duvander, Ann-Zofie, and Tommy Ferrarini (2013), ‘Sweden's family policy under change: Past, present and future', Friedrich Ebert Stiftung International Policy Analysis. https://library.fes.de/pdf-files/id/10232.pdf (accessed July 6, 2021).

Duvander, Ann-Zofie, Linda Haas and Philip Hwang (2017), 'Country notes: April 2017. Sweden', in Sonja Blum, Alison Koslowski and Peter Moss (eds), 13th International Review of Leave Policies and Research 2017, pp. 392-400. www .leavenetwork.org/fileadmin/user_upload/k_leavenetwork/annual_reviews/2017 Leave Review 2017 final2.pdf (accessed October 30, 2020).

Duvander, Ann-Zofie, and Ida Viklund (2020), 'How long is a parental leave and for whom? An analysis of methodological and policy dimensions of leave length and division in Sweden', International Journal of Sociology and Social Policy, 40 (5/6), 479-494.

Esping-Andersen, Gøsta (1999), The Social Foundations of Post-Industrial Economies. Oxford: Oxford University Press.

Esping-Andersen, Gøsta, Anton Hemerijck, Duncan Gallie and John Myles (2002), Why We Need a New Welfare State. Oxford: Oxford University Press.

Eurostat (2020), Database. http://ec.europa.eu/eurostat/data/database (accessed August $3,2020)$.

Fenwick, Clare (2019), 'The political economy of immigration and welfare state effort: Evidence from Europe', European Political Science Review, 11, 357-375.

Ferrarini, Tommy, and Ann-Zofie Duvander (2010), 'Earner-carer model at the cross-roads: Reforms and outcomes of Sweden's family policy in comparative perspective', International Journal of Health Services, 40 (3), 373-398.

Finseraas, Henning (2008), 'Immigration and preferences for redistribution: An empirical analysis of European survey data', Comparative European Politics, 6, 407-431.

Goldscheider, Frances K., Eva Bernhardt and Trude Lappegård (2015), 'The gender revolution: A framework for understanding changing family and demographic behavior', Population and Development Review, 41 (2), 207-239. 
Gros, Daniel, and Alfred Steinherr (2004), Economic Transition in Central and Eastern Europe: Planting the Seeds. Cambridge: Cambridge University Press.

INED (2013), Developed countries database. www.ined.fr/en/pop_figures/developed countries_database/ (accessed July 3, 2013).

Komp, Kathrin, and Theo Van Tilburg (2010), 'Ageing societies and the welfare state: Where the inter-generational contract is not breached', International Journal of Ageing and Later Life, 5 (1), 7-11.

Lennartz, Christian, and Richard Ronald (2017), 'Asset-based welfare and social investment: Competing, compatible, or complementary social policy strategies for the new welfare state?', Housing, Theory and Society, 34 (2), 201-220.

Lesthaeghe, Ron (2010), 'The unfolding story of the Second Demographic Transition', Population and Development Review, 36 (2), 211-251.

Lewis, Jane (2006), 'Gender and welfare in modern Europe', Past \& Present, 1 (Suppl 1), 39-54.

Macura, Miroslav, Alphonse L. MacDonald and Werner Haug (eds) (2005), The New Demographic Regime: Population Challenges and Policy Responses. New York, NY: United Nations.

Matysiak, Anna, Marta Styrc and Daniele Vignoli (2014), 'The educational gradient in marital disruption: A meta-analysis of European research findings', Population Studies, 68 (2), 197-215.

McDonald, Peter (2006), 'Low fertility and the state: The efficacy of policy', Population and Development Review, 32 (3), 485-510.

Morel, Nathalie, Bruno Palier and Joakim Palme (eds) (2012), Towards a Social Investment Welfare State? Ideas, Policies and Challenges. Bristol: Policy Press.

Mussino, Eleonora, Ann-Zofie Duvander and Li Ma (2018), 'Does time count? Immigrant fathers' use of parental leave for a first child in Sweden', Population, 73 (2), 363-382.

OECD (2020), 'Family database: Indicators'. www.oecd.org/social/family/database .htm (accessed September 6, 2020).

Oláh, Livia Sz., and Eva M. Bernhardt (2008), 'Sweden: Combining childbearing and gender equality', Demographic Research, 19 (28), 1105-1144.

Oláh, Livia Sz., Irena E. Kotowska and Rudolf Richter (2018), 'The new roles of men and women and implications for families and societies', in Gabriele Doblhammer and Jordi Gumà (eds), A Demographic Perspective on Gender, Family, and Health in Europe. Cham: Springer, pp. 41-64.

Orloff, Ann Shola (1993), 'Gender and the social rights of citizenship: The comparative analysis of gender relations and welfare states', American Sociological Review, 58 (3), 303-328.

Palier, Bruno (ed.) (2010), A Long Goodbye to Bismarck? The Politics of Welfare Reform in Continental Europe. Amsterdam: Amsterdam University Press.

Pateman, Carol (1988), The Sexual Contract. Stanford, CA: Stanford University Press.

Perelli-Harris, Brienna, and Nora Sánchez Gassen (2012), 'How similar are cohabitation and marriage? Legal approaches to cohabitation across Western Europe', Population and Development Review, 38 (3), 435-467.

Ranson, Gillian (2001), 'Men at work: Change or - no change? - in the era of the "New Father"', Men and Masculinities, 4 (1), 3-26.

Skolverket (2020), Statistik om förskola. www.skolverket.se/skolutveckling/statistik/ sok-statistik-om-forskola-skola-och-vuxenutbildning?sok=SokC\&verkform $=\mathrm{F} \% \mathrm{C} 3$ \%B6rskola\&omrade=Barn\%20och\%20grupper\&lasar=1998\&run=1 (accessed September 1, 2020). 
Sobotka, Tomáš, and Laurent Toulemon (2008), 'Overview Chapter 4: Changing family and partnership behavior - Common trends and persistent diversity across Europe', Demographic Research, 19 (6), 85-138.

Taylor-Gooby, Peter (2004), 'New risks and social change', in Peter Taylor-Gooby (ed.), New Risks, New Welfare: The Transformation of the European Welfare State. Oxford: Oxford University Press. https://oxford.universitypressscholarship.com/ view/10.1093/019926726X.001.0001/acprof-9780199267262-chapter-1

Thévenon, Olivier (2011), 'Family policies in OECD countries: A comparative analysis', Population and Development Review, 37 (1), 57-87.

Turunen, Jani (2017), 'Shared physical custody and children's experience of stress', Journal of Divorce \& Remarriage, 58 (5), 371-392.

Van Bavel, Jan, Christine R. Schwartz and Albert Esteve (2018), 'The reversal of the gender gap in education and its consequences for family life', Annual Review of Sociology, 44, 341-360.

Wilson, Chris, Tomáš Sobotka, Lee Williamson and Paul Boyle (2013), 'Migration and intergenerational replacement in Europe', Population and Development Review, 39 (1), 131-157.

Wincott, Daniel (2013), 'The "Golden Age" of the welfare state: Interrogating a conventional wisdom', Public Administration, 91 (4), 806-822. 